\title{
Giant Renal Angiomyolipoma with Spontaneous Retroperitoneal Hemorrhage: A Case Report
}

\section{Retroperitoneal Kanamaya Neden Olan Dev Renal Anjiomyolipoma Olgusu}

\author{
Rıdvan Özbek ${ }^{1}$, Erdem Öztürk ${ }^{1}$, Taha Numan Yıkılmaz ${ }^{1}$, Onur Kekilli ${ }^{1}$, Halil Başar ${ }^{1}$ \\ ${ }^{1}$ Dr. Abdurrahman Yurtaslan Onkoloji Eğitim ve Araştırma Hastanesi, Üroloji, Ankara
}

Dergiye Ulaşma Tarihi:26,01,2018 Dergiye Kabul Tarihi:16,04,2018 Doi: 10.5505/aot.2018.88609

\section{ÖZET}

Anjiomyolipoma renal tümörlerin yaklaşık \%5'ini oluşturur. Benign karekterde olduklarından, tanı konmadan önce büyük boyutlara ulaşabilirler. Kitle boyutu $4 \mathrm{~cm}$ 'den küçük lezyonlar çoğunlukla asemptomatiktir. Boyutu $4 \mathrm{~cm}$ 'den büyük lezyonlarda intratümöral ya da perinefritik hemoraji riski artar ve lezyon semptomatik hale gelebilir. Tedavi yaklaşımları, tümörün boyutuna ve komplikasyonlarına bağlı değişir. Ultrasonografi ve bilgisayarlı tomografi, kitlenin boyutu, iç yapısı ve komplikasyonlarının değerlendirilmesinde, böylelikle böbrek koruyucu cerrahi yaklaşımlara yön vermesinde değerlidir. Biz olgumuzda spontan retroperitoneal kanamaya neden olmuş $13 \mathrm{~cm}$ boyutundaki renal anjımyolıpomayı sunmayı amaçladık

Anahtar Kelimeler: Renal anjiyomyolipoma, Wunderlich Sendromu, Nefrektomi

\begin{abstract}
Angiomyolipomas form approximately 5\% of renal tumors. Because of their benign character, they may reach extensive sizes before the diagnosis. They are usually asymptomatic if the tumor size is less than $4 \mathrm{~cm}$. İn angiomyolipomas greater than $4 \mathrm{~cm}$, there is an increased risk of intratumoral or perinephritic hemorrage and patients may be come symptomatic. Therapeutic approach, differs with respect to size of the tumor and complications. Ultrasonography (US) and computed tomography (CT) are important in evaluating the tumor size, internal structure of tumor and complications. İn that way, nephron sparing surgery can be planned. We aimed to present a case of spontaneous retroperitoneal hemorrhage, in a patient with $13 \mathrm{~cm} \mathrm{renal}$ anjiomyolipoma.
\end{abstract}

Keywords: Renal anjiomyolipoma, Wunderlich's Syndrome, Nephrectomy

\section{GíRiş}

Anjiyomyolipoma (AML) matür yağ hücreleri, düz kas dokusu ve kalın duvarlı kan damarlarını değişen oranlarda içeren, mezenşimal kaynaklı benign bir tümördür(1). AML popülasyonda $\% 0.3$ oranında görülür ve solid böbrek kitlelerinin \% 5'ini oluşturur (29). En sik böbrekten kaynaklanır, daha az sıklıkla karaciğer, lenf nodları, dalak, akciğer ve retroperitoneal alanda görülür. Benign karakterde olduğu için tanı konulmadan önce büyük boyutlara ulaşabilir ve hatta tümör içi hemoraji gelişirse (Wunderlich Sendromu) acil tedavi gerektirebilir.

\section{OLGU SUNUMU}

Şiddetli sol yan ağrısı ve halsizlik nedeniyle acil servise başvuran elli bir yaşında kadın hastanın öyküsünde; daha önceden sol böbrekte AML tanıs1 aldı $\breve{g} 1$, takiplerine gitmediği öğrenildi. Fizik muayenede; sol yan tarafta kostovertebral açı hassasiyeti, batında hassasiyet ve defans bulgusu vardi. Laboratuvar bulgularında hemoglobin değeri $7.03 \mathrm{~g} / \mathrm{dl}$, hematokrit değeri $\% 23.5$, serum kreatinin değeri $1.06 \mathrm{mg} / \mathrm{dl}$, diğer rutin biyokimya değerleri ve APTT, protrombin zamanı, INR değeri normal sınırlar içindeydi. Tansiyon arteryel 100/70 mmhg, ateş: $37.5 \mathrm{C}$ ölçüldü. 
Abdominal ultrasonografi (USG) incelemesinde; sol böbrek hiler bölgeden mediale ve superiora uzanım gösteren,hiperekojen, $10 \mathrm{~cm}$ boyutunda, içerisinde vasküler yapılarda barındıran Anjiyomyolipomayı düşündüren kitle lezyonu izlendi. Hastaya $3 \ddot{U}$ eritorosit süspansiyonu replasmanı yapıldı. Hasta selektif arteryel embolizasyon açısından girişimsel radyolojiye danışıldı. Girişimsel radyoloji tarafindan selektif arteryel embolizasyon yapıldı (Figür $1)$.

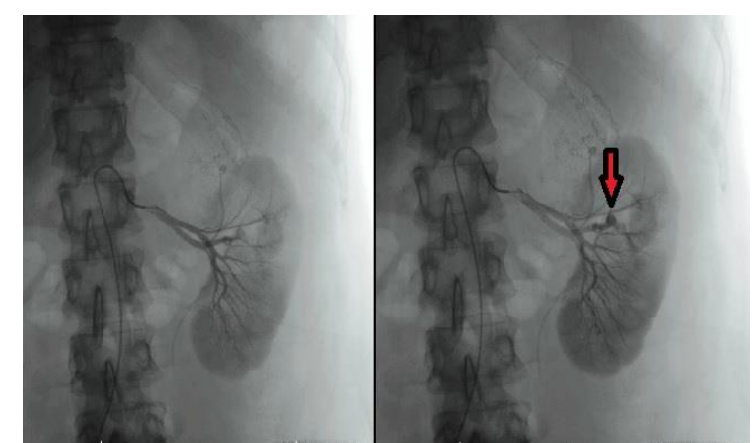

Figür 1: Girişimsel Radyoloji tarafından embolizasyon uygulanan rüptüre olmuş vasküler yapı.

İşlem sonrası intravenöz kontrast madde verildikten sonra çekilen bilgisayarlı tomografide (BT)sol böbrek lojunda yaklaşık 124x120 mm boyutlarında, yağ dansitesinde hipodens alanlar barındıran, superolateral kesimde $\quad 38 \mathrm{~mm}$ kalınlıkta hiperdens komponent içeren, anjioyomyolipomay1 düşündüren kitle izlendi. Böbrek dokusu süperior kesimde renal arter distal uç lokalizasyonunda belirgin artefakt oluşturan embolizasyon materyali lehine hiperdens oluşum saptandı. Sağ böbrek normal izlendi (Figür 2). Girişimsel radyolojide selektif arteryel embolizasyon uygulandiktan sonra elektif şartlarda operasyona alınan hastaya total nefrektomi yapıldı (Figür 3). Peroperatif komplikasyon olmayan hastanın postoperatif 5 . gün dreni alındı ve taburcu edildi. Preoperatif AML tanis1, operasyon sonras1 patoloji ile de doğruland. Makroskobik görünümde 13,5x10x6 $\mathrm{cm}$ boyutlarında böbrek üst ve orta polünde yerleşim gösteren kitle lezyonu izlendi. Mikroskobik görünümde ise sitoplazmanın periferine yerleşmiş, normokromik nükleuslu, geniş vakuole sitoplazmalı matür adipositler, duvarı hyalinize vasküler yapılar ve damar duvarından köken almış görünümde iğsi hücreler izlendi.
İmmünohistokimyasal çalışmada lezyonu oluşturan hücrelerde HMB45, aktin, desmin ile pozitif boyanma tespit edildi.

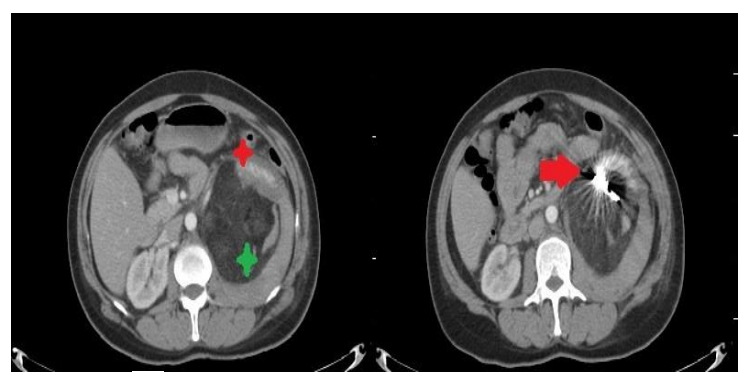

Figür 2: † Yağ içeriğinden zengin

Anjiomyolipoma olduğu düşünülen kitle lezyonu, † sol böbrek, sağ resimde ok işaretiyle gösterilen alan girişimsel radyoloji tarafindan uygulanan embolizasyon materyali.

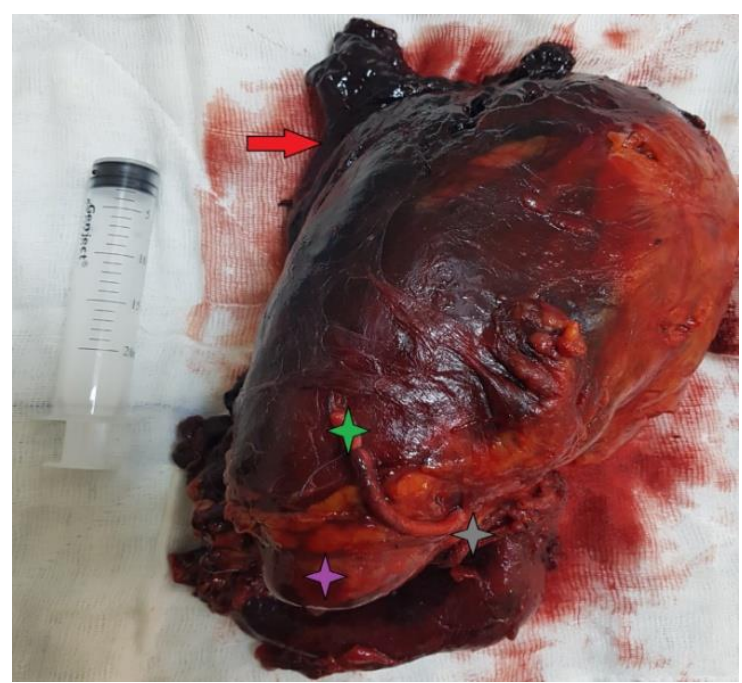

Figür 3 : † sol üreter, † sol böbrek alt polü, † sol renal hilus, ok işaretiyle gösterilen alan sol böbrek posteriorunda organize hematom.

\section{TARTIŞMA}

AML kalın duvarlı anevrizmal damarlar, düz kas dokusu ve değişik düzeylerde adipöz dokudan oluşan benign bir neoplazmdır. İlk olarak 1951 yılında Morgan tarafindan tanımlanmıştır(3). Ancak şu an için anjiomyolipomanın perivasküler epiteloid hücrelerden (PEC) farklılaştığı, nöral krest kökenli olduğu kabul edilmektedir(4). Tümör kadınlarda önemli düzeyde östrojen reseptörü sentezlemekte ve bu yolla potansiyel hormonal etki oluşturmaktadır. Olguların \%80'i sporadik ve soliterdir. Sporadik anjiyomyolipomalar yavaş büyüme eğilimindedir, genelde insidental olarak saptanır. Olguların \%20'si ise 
Tuberoskleroz (TS) kompleksi ya da nadiren pulmoner lenfanjiomyomatozisin(LAM) parçası olarak karşımıza çıkmaktadır (5). Anjiyomyolipomaların çoğunluğu benign karakterli olmasına rağmen, küçük bir kısmı agresif davranış paternine sahip olup lokal invazyon oluşturabilir. Klasik ve epiteloid olmak üzere iki histolojik tipi bulunmaktadır. Epiteloid AML, AML'nın malign transformasyon gösterme eğilimi olan ender bir çeşididir ve daha çok Tuberoskleroz kompleksi ile birlikte bulunur.

Renal anjiomyolipomanın en ciddi komplikasyonu olan "Wunderlich Sendromu" ya da masif retroperitonel hemoraji hastaların \%10 undan fazlasında bildirilmiştir ve eğer, uygun tedavi yapılmazsa belirgin morbidite ve potansiyel mortaliteye sahiptir. Anjiomyolipoma spontan retroperitoneal kanamanın en sık sebebidir. Boyutta artış ( $>4$ $\mathrm{cm})$, multifokal olması ve tuberoskleroz ile birlikteliği kanama riskini arttırır(5). Yan ağrıs1 veya karın ağrısı, palpabl kitle ve gross hematüriyi içeren Lenck triadı, Wunderlich Sendromunun klasik bulgusudur(6). Olgumuzda acil servise yaşamı tehdit eden hemoraji ve şiddetli yan ağrısı nedeniyle başvurdu.

AML tanısında radyolojik görüntüleme yöntemlerinin önemi büyüktür ve diğer böbrek tümörlerinden karakteristik radyolojik görünümleri ile ayırt edilebilirler.USG de düzgün sinırl1, gölgelenme veren, yüksek ekojenik lezyonlar şeklinde görüntülenir (6). BT'de renal lezyon içerisinde yağ dokusu varlığ1 ( $\leq-20$ hounsfield unite) ayırt edici özelliktir(7-8). Yağ baskılı magnetik rezonans görüntüleme tanı için oldukça fikir vericidir. Yağ komponenti içeren renal hücreli karsinom, lipom, liposarkom, onkositom, Wilms tümörü ve teratom gibi yağ içeren tümörler ayırıcı tanıda düşünülmelidir. Abdominal BT;anjiomyolipoma varlığı ve kanama gibi

\section{REFERANSLAR}

1. Shankar S, Hulikanthimatt KS, Awatti SM, Narayanrao ST: Bilateral multifocal renal angiomyolipoma associated with Wunderlich's syndrome in a tuberousclerosis patient. J Clin Diagn Res, 2015; 9(8): ED01-3 komplikasyonların belirlenmesinde en duyarlı yöntemdir.

Asemptomatik, 4 cm'den küçük AML'lerde konservatif tedavi seçeneği uygulanır. Boyutu $4 \mathrm{~cm}$ 'den büyük AML'lerde ise tedavi seçeneği tartışmalıdır. Ancak takip edilmesi güç yüksek riskli hastalarda ve gebe kalmayı planlayan genç kadınlarda profilaktik vaskuler embolizasyon uygulanabilir(9). Yapılan bazı çalışmalarda, embolizasyonun böbrek fonksiyonlarını koruyup tümör boyutunu azalttığı gösterilmiştir(9).

Semptomatik hastalarda selektif embolizasyon, nefron koruyucu cerrahi ve total nefrektomi tedavi seçeneği olarak düşünülebilir. Selektif embolizasyon Wunderlich Sendromu vakalarında, özellikle bilateral ve multiple anjiomyolipomu olan tüberosklerozlu hastalarda ve önceden var olan böbrek yetmezliği durumunda tercih edilir(8). Hayatı tehdit eden kanama durumunda total nefrektomiyide içeren acil ameliyat gerekebilir. Olgumuzda olduğu gibi öncelikle hastaya selektif arteryel embolizasyon uyguland1, ardından elektif olarak hastaya nefrektomi uyguland.

\section{Sonuç}

Anjiomyolipomalar nadir görülen benign böbrek tümörleridir. Büyük tümör boyutu ve tüberosklerozla birlikteliği retroperitoneal hemoraji gibi komplikasyonları arttırır. Dev renal AML'si görüntüleme ile tanımlanabilir. Tanı histopatolojik inceleme ve immünohistokimyasal çalışma ile doğrulanır. Yüksek kanama riski taşıyan kitlelerde, kanama riskini azaltmak ve dev kitlenin neden olduğu bası bulgularını ortadan kaldırmak için konservatif tedavi yerine parsiyel veya total nefrektomi tercih edilir.

\section{Çıkar Çatışması: yok}


the family of lesions characterized by the presence of perivascular epithelioid cells. Am J Surg Pathol. 20 (1996)722-730.

5. Seyam RM, Bissada NK, Kattan SA, Mokhtar AA, Aslam M, Fahmy WE, Mourad WA, Binmahfouz AA, Alzahrani HM, Hanash KA. Changing trends in presentation, diagnosis and management of renal angiomyolipoma: comparison of sporadic and tuberoussclerosis complex-associated forms. Urology 2008; 72: 1077-1082.

6. G. Albi, L. del Campo, D. Tagarro, Wunderlich's syndrome: causes, diagnosis and radiological management, Clin. Radiol. 57 (9) (2002) 840-845.
7. Lemaitre L, Claudon M, Dubrulle F, Mazeman E. İmaging of angiomyolipomas. Semin Ultrasound CT MR 1997; 18: 100-114

8. Simpfendorfer C, Herts BR, Motta-Ramirez GA, Lockwood DS, Zhou M, Remer EM. Angiomyolipoma with minimal fat on MDCT: can counts of negative- attenuation pixels aid diagnosis? AJR Am J Roentgenol. 2009; 192: 438-443

9. Nelson CP, Sanda MG .Contemporary diagnosis and management of renal angiomyolipoma. J urol. 2002 168: $1315-1325$. 